\title{
A review of the safety and efficacy of current COVID-19 vaccines
}

\author{
Zehong Huang, Yingying Su, Tianying Zhang, Ningshao Xia (凶)
}

State Key Laboratory of Molecular Vaccinology and Molecular Diagnostics, National Institute of Diagnostics and Vaccine Development in Infectious Diseases, Strait Collaborative Innovation Center of Biomedicine and Pharmaceutics, School of Public Health, Xiamen University, Xiamen 361102, China

(C) Higher Education Press 2022

\begin{abstract}
Vaccination is the most effective and feasible way to contain the coronavirus disease 2019 (COVID-19) pandemic. The rapid development of effective COVID-19 vaccines is an extraordinary achievement. This study reviewed the efficacy/effectiveness, immunogenicity, and safety profile of the 12 most progressed COVID-19 vaccines and discussed the challenges and prospects of the vaccine-based approaches in a global crisis. Overall, most of the current vaccines have shown safety and efficacy/effectiveness during actual clinical trials or in the realworld studies, indicating a development of pandemic control. However, many challenges are faced by pandemic control in terms of maximizing the effect of vaccines, such as rapid vaccine coverage, strategies to address variants with immune escape capability, and surveillance of vaccine safety in the medium- and long-terms.
\end{abstract}

Keywords COVID-19; SARS-CoV-2; vaccine; safety; efficacy; effectiveness; immunogenicity

\section{Introduction}

The pandemic of coronavirus disease 2019 (COVID-19), which is caused by severe acute respiratory syndrome coronavirus 2 (SARS-CoV-2), has substantially affected public health, the economy, and society worldwide. As of August 9, 2021, more than 200 million confirmed cases of COVID-19 and more than 4 million deaths had been reported to the World Health Organization (WHO) [1]. Non-pharmaceutical interventions (NPIs) are mainly employed for achieving control over the epidemic and suppressing SARS-CoV-2 transmission [2]. However, researchers believe that the world will not return to normal until safe and effective vaccines are widely available. Considering the unprecedented effect of the pandemic, scientists, vaccine manufacturers, and regulatory agencies in many countries quickly responded and launched a "saturated" research and development competition to generate COVID-19 vaccines, with all technological routes operating in tandem. Currently, more than 290 vaccines are being developed, and more than 100 vaccines are under-

Received May 30, 2021; accepted August 24, 2021

Correspondence: Ningshao Xia, nsxia@xmu.edu.cn going clinical trials [3].

As of July 2021, 12 COVID-19 vaccine manufacturers have released the results of phase 3 clinical trials, including four inactivated, four non-replicating viral vector, three RNA-based, and one protein subunit vaccines. Among these vaccines, three inactivated vaccines (BBIBP-CorV, CoronaVac, WIV04) and one adenoviral vector vaccine (Ad5-nCoV) received the conditional marketing authorization in China [4-7]. Two RNA-based vaccines (BNT162b2 and mRNA-1273) and one adenoviral vector vaccine (Ad26.COV2.S) received emergency use authorization for the first time in USA [8]. An adenoviral vector vaccine (AZD-1222) was first approved in the UK [9]. One adenovirus vector vaccine (Gam-COVID-Vac) registered in Russia [10]. An inactivated vaccine (COVAXIN) was first licensed in India [11]. After being licensed in the countries of origin, some vaccines were approved for use in other countries (details in Table 1). In addition, BBIBPCorV, CoronaVac, BNT162b2, mRNA-1273, mRNA1273, and Ad26.COV2.S are included in the WHO emergency use listings [12]. A two-dose immunization schedule is implemented for most vaccines $(83 \%, 10 / 12)$, and a one-dose schedule is implemented for two vaccines $(17 \%)$. The present review summarizes the safety and efficacy of the 12 current COVID-19 vaccines and discusses the challenges in developing vaccines against SARS-CoV-2 variants. 


\section{Efficacy and effectiveness}

\section{Efficacy in clinical trials}

In phase 3 clinical trials of COVID-19 vaccines, the two key efficacy endpoints are protection against symptomatic COVID-19 cases and protection against severe disease. The efficacy of each vaccine is summarized in Table 1 . Reports on the efficacy are available for 12 vaccines, and all the vaccines except $\mathrm{CVnCoV}$ were above the criterion set by the WHO Target Product Profiles for COVID-19 vaccines (50\%) [13]. The efficacies of RNA-based vaccines mRNA-1273, BNT162b2, and $\mathrm{CVnCoV}$ are 94.1\%, 95.0\%, and 48\% against symptomatic COVID-19 cases and 100\%, 88.9\% (after dose 1), and 77\% (in the age group of 18-60 years) against severe disease or moderateto-severe disease, respectively [14-16]. The efficacies of adenoviral vector vaccines AZD-1222 and Gam-COVIDVac with a two-dose regimen are $64.2 \%$ and $91.6 \%$ against symptomatic cases and $85.4 \%$ and $100 \%$ against severe disease or moderate-to-severe disease, respectively $[17,18]$. The efficacies of single-dose adenoviral vector vaccines $\mathrm{Ad} 26 . \mathrm{COV} 2 . \mathrm{S}$ and $\mathrm{Ad} 5 \mathrm{-nCoV}$ are $66.5 \%$ and $68.83 \%$ against symptomatic cases and $85.4 \%$ and $95.47 \%$ against severe disease, respectively [7,19]. Efficacy Data have been reported for four inactivated vaccines. The efficacies of BBIBP-CorV against symptomatic and severe diseases were $78.1 \%$ and $100 \%$, respectively [20]. Similar to BBIBP-CorV, the efficacies of COVAXIN were $77.8 \%$ and $93.4 \%$ for symptomatic and severe diseases, respectively [21]. In addition, the efficacies of WIV04 were $72.8 \%$ and $100 \%$ against symptomatic and severe diseases, respectively [20]. The efficacy of CoronaVac varies widely across countries. For symptomatic cases, the efficacies of CoronaVac are $83.5 \%, 65.30 \%$, and $50.7 \%$ in Turkey, Indonesia, and Brazil, respectively, and $100 \%$ for severe cases in Brazil [22-25]. Among the protein subunit vaccines, only NVX-CoV2373 with the Matrix-M adjuvant has efficacy Data of $89.7 \%-90.4 \%$ against symptomatic cases and $100 \%$ against severe disease [26,27]. Notably, the efficacy of these vaccines may not be directly comparable because of differences in study design, population, sites, time, and cases surveillance systems.

\section{Effectiveness in real-world}

The actual effectiveness of five vaccines (BNT162b2, mRNA-1273, AZD-1222, CoronaVac, and Ad26.COV2.S) has been reported in several countries, and the findings were all consistent with the efficacy observed in clinical trials. The majority of prospective studies of effectiveness were conducted in Israel, United States, and UK (Table 1). Israel's mass vaccination campaigns with BNT162b2 was launched on December 20, 2020. As of February 24, 2021, $68.7 \%$ of Israelis older than 16 years had received their first vaccine dose, making it one of the fastest vaccination campaigns in the world [28]. The efficacies of BNT162b2 against symptomatic cases, hospitalizations, and severe diseases were $94 \%, 87 \%$ and $92 \%$, respectively, after the second dose in Israel [29]. In terms of the effect of vaccination campaigns at the population level, a large and early decrease in COVID-19 cases and hospitalizations were observed in elderly individuals who were prioritized and therefore received the vaccine earlier and in cities that started vaccination early [28]. The dynamic of the second wave of the pandemic (third lockdown plus vaccine campaigns) differed substantially across age groups, which was not observed in the first wave (second lockdown) [28]. This scenario demonstrates the effectiveness of nationwide vaccination campaigns in Israel. The CoronaVac study in Chile also showed effectiveness levels of $65.9 \%, 87.5 \%$, $90.3 \%$, and $86.3 \%$ against symptomatic cases, hospitalization cases, cases requiring admission to the ICU, and confirmed death [30]. Ad26.COV.S showed a similar efficacy (76.7\% against SARS-CoV-2 infection) to that reported in the phase 3 clinical trial [31]. Furthermore, in the United States, the actual effectiveness of single-dose mRNA vaccines reached $80 \%$ [32], although most of the partially immunized results included Data between two doses and may not accurately reflect the effectiveness of a single dose of a vaccine. In addition to the effectiveness of the vaccine, the effects of vaccination campaigns nationwide depend on the vaccine coverage, the timing of vaccine campaign initiation, and the behavior of vaccinated individuals [33]. Earlier, more proactive, and largerscale vaccine campaigns are urgently needed worldwide to control the COVID-19 pandemic.

Considering the lack of head-to-head clinical trials, the comparison of the efficacy of different vaccines is inappropriate. However, in the real world, when multiple vaccinations are used in the same region or country, the effectiveness of different vaccines may be compared. A study in the US revealed that the adjusted effectiveness of BNT162b2 and mRNA-1273 were 93\% (95\% CI 78\%98\%) and $82 \%$ (95\% CI 20\%-96\%) against SARS-CoV-2 infection, respectively [34]. One test negative case control study showed that the adjusted effectiveness of AZD-1222 was lower than that of BNT162b2 against symptomatic diseases caused by the Alpha (66.1\% vs. $93.4 \%$ ) or Delta variants $(87.9 \%$ vs. $59.8 \%)$ [35]. However, the effectiveness of AZD-1222 and BNT162b2 against hospitalizations caused by the Alpha (86\% vs. $95 \%$ ) or Delta variants $(92 \%$ vs. $96 \%$ ) was similar with that in England [36]. Studies in Scotland also showed no substantial difference in the effectiveness of a single dose of AZD-1222 or BNT162b2 in hospital admission ( $88 \%$ vs. $91 \%$ at $28-34$ days postvaccination) [37].

The duration of protection also raises great concerns, which is best evaluated by ongoing blinded follow-up of placebo group in phase 3 trial [38]. However, ethical 


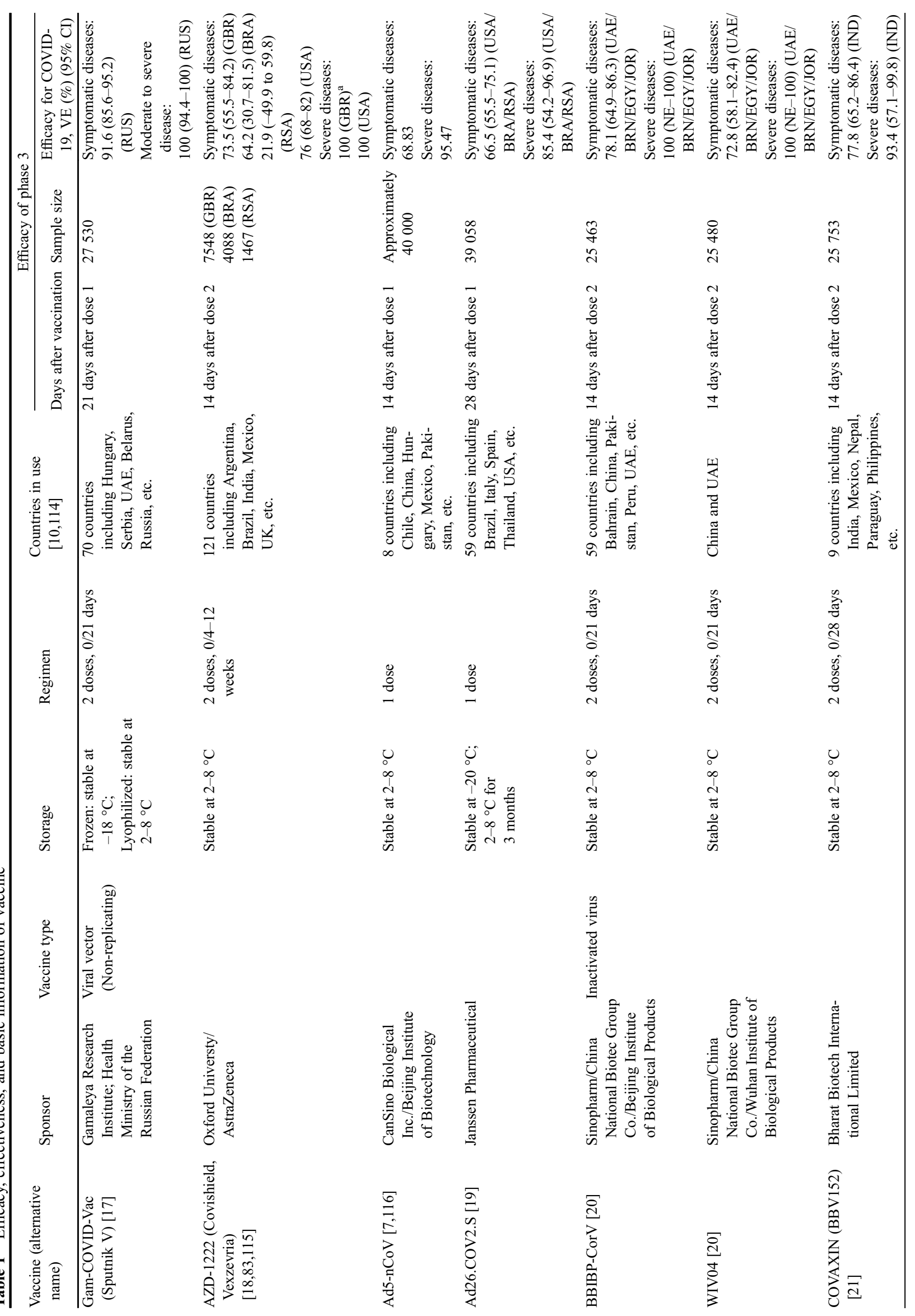




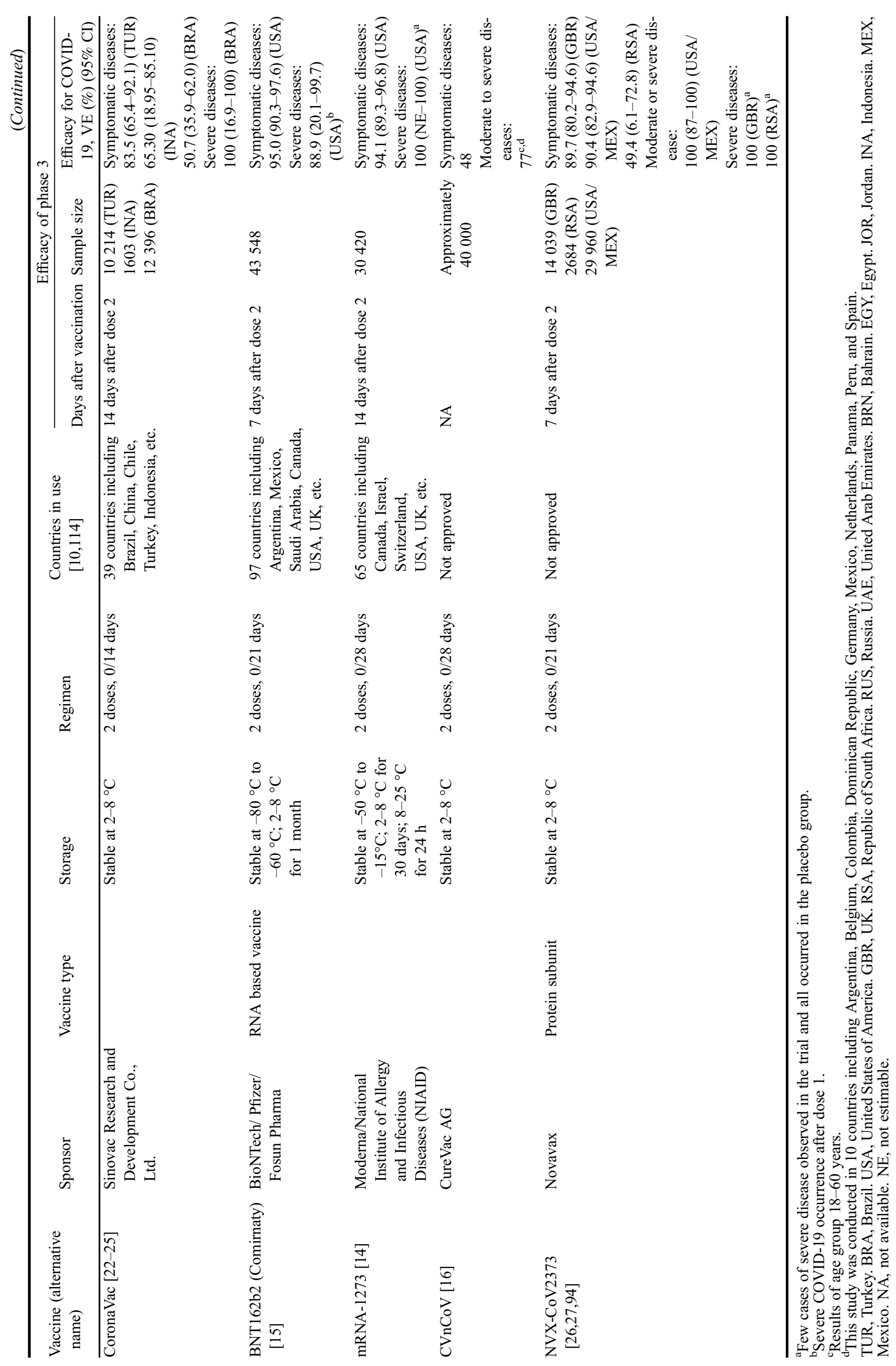


considerations require that vaccines are provided to the placebo group in a timely manner during the pandemic [39]. The blind crossover design would be the preferred way to assess the durability of COVID-19 vaccine efficacy even after placebo group participants receive the vaccine [40]. In addition, real-world studies are important to assess the long-term protective effects of vaccines. Currently, Data on the long-term efficacy of the vaccine are lacking because of the relatively short period of time since phase 3 studies are launched.

\section{Immunogenicity}

\section{Neutralizing antibodies}

Vaccine-elicited neutralizing antibody titers can offer a comparable protection as COVID-19 vaccines [41]. Neutralizing activity was assessed by live virus neutralization assays for most vaccines. The seroconversion rate was
96\%-100\% for all vaccines, except for Ad5-nCoV (47\%) [42-54]. Considering the diversity in testing methodologies and lack of head-to-head clinical trials, vaccineinduced neutralizing antibody levels cannot be compared directly. Data are available on neutralizing antibody levels in both vaccinated and convalescent patients for nine vaccines, including Gam-COVID-Vac, AZD-1222, Ad26. COV2.S, COVAXIN, CoronaVac, BNT162b2, mRNA1273, CVnCoV, and NVX-CoV2373. The relative levels of neutralizing antibodies are summarized in Fig. 1. For vaccines with a two-dose immunization schedule, the neutralizing antibody titers peaked at 7-21 days after the second dose.

Based on the peak neutralizing antibody titer, the mRNA-1273, BNT162b2, and NVX-CoV2373 resulted in relatively high neutralizing antibody titers, reaching 3.4-4 times the GMT in convalescent serum [45,46,50]. Adenovirus vector vaccines with a two-dose schedule (Gam-COVID-Vac and AZD-1222) and COVAXIN resulted in peak neutralizing antibody titers approximately
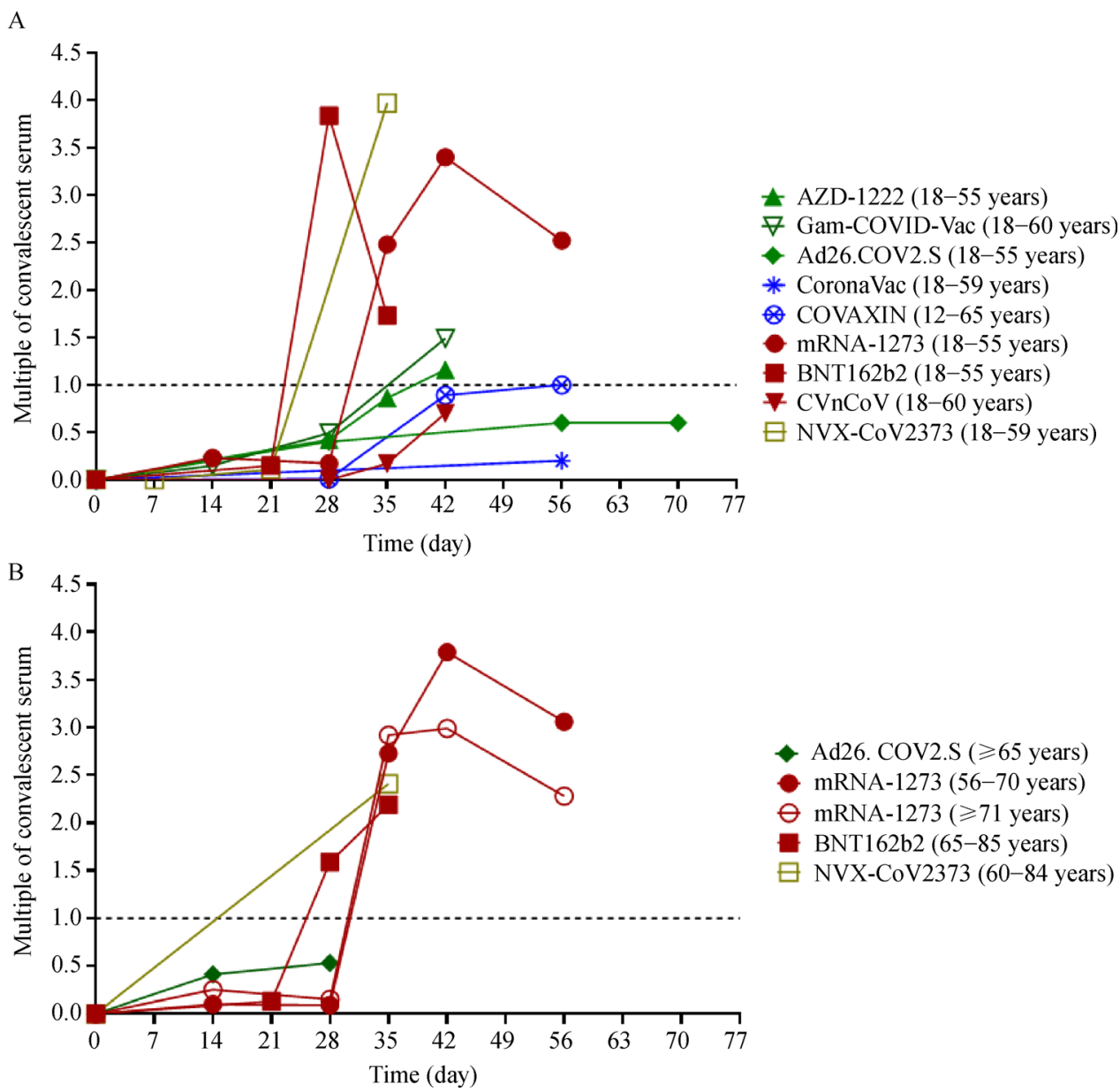

Fig. 1 Comparison of neutralizing antibody titers after vaccination with different vaccines in younger and older participants. (A) Comparison in younger adult participants. (B) Comparison in elderly participants. The colors green, red, blue, and mustard yellow represent adenovirus vector vaccines, RNA-based vaccines, inactivated virus vaccines, and protein subunit vaccines, respectively. 
$1-2$ times that in convalescent serum $[43,44,47]$. The peak neutralizing antibody titers after vaccination with CoronaVac, Ad26.COV2.S, and $\mathrm{CVnCoV}$ were $0.3-0.7$-fold that in convalescent serum $[49,53,55]$ (Fig. 1A). One concern with the use of adenoviral vector vaccines is the preexisting immunity to adenovirus. AZD-1222 had no relationship between the presence of low-level antibodies to ChAdOx1 at baseline and the ELISA titer to SARS$\mathrm{CoV}-2$ spike protein after vaccination in phase 2 clinical trial, but Data from subjects with high-level antibodies are lacking [44]. The presence of pre-existing immune responses to vaccine vectors components $(\mathrm{rAd} 26$ and rAd5) does not affect the titer of RBD-specific antibodies in the serum of participants in the phase $1 / 2$ study of GamCOVID-Vac [47]. However, in participants who received the Ad5-nCoV vaccine, RBD-specific enzyme-linked immunosorbent assay (ELISA) antibody and neutralizing antibody levels in participants with low pre-existing Ad5 antibodies $(\leqslant 1: 200)$ were approximately two-fold higher than that in participants with high pre-existing Ad5 antibodies (>1:200) [54]. The effect of pre-existing immunity on the immune response after AD26.COV2.S immunization has not been reported.

Only four vaccine manufacturers have reported comparable neutralizing antibody results in the elderly population $[42,45,49,50]$. The immune response in the elderly population is weaker than that in younger adult participants. The peak neutralizing antibody titers after vaccination with RNA vaccines and NVX-CoV2373 were 2-4fold that in convalescent serum $[42,45,50]$, whereas those after vaccination with Ad26.COV2.S were approximately 0.5-fold that in convalescent serum [49] (Fig. 1B).

The currently available vaccines cannot induce a high level of neutralizing antibodies within 3 weeks after the priming vaccination. Vaccines that can induce a rapid response of neutralizing antibodies may be one of the key targets of future vaccine development. In addition, the indirect comparison of the relative levels of neutralizing antibodies was influenced by the composition of the convalescent serum panels, which varies across studies.

\section{Cell-mediated immunity}

Considering that SARS-CoV-2 is a mucosal pathogen, adaptive $\mathrm{T}$ cell immunity is also important for control and clearance [56]. Flow cytometry and IFN- $\gamma$ ELISpot are mainly used to assess the cellular immune response. Cellular immunoassay indicators vary among different vaccine clinical trials, including $\mathrm{CD} 8^{+} \mathrm{T}$ cell, $\mathrm{CD} 4^{+} \mathrm{T}$ cell, and IFN- $\gamma$. Most vaccines invoke a significant $\mathrm{T}$ cell immune response with a Th1 response bias, yielding a balanced Th1/Th2 response [42,43,46-49,51-54,57,58]. Considering the differences in assay methods and indicators, we failed to compare the $\mathrm{T}$ cell responses of different vaccines.

\section{Safety}

\section{Pre-licensure evaluation}

The safety profile is critical to evaluating a vaccine, because these vaccines are administered to healthy populations. For mRNA vaccines, the most common adverse reactions include short-term mild-to-moderate pain at the injection site, fatigue, headache, myalgia, arthralgia, and chills. The incidence and severity of adverse reactions increase after the second dose [14,15]. Adverse reactions are less common and less severe in older participants than in younger participants. A proportion of subjects have experienced grade 3 or above adverse reactions. The frequency of grade 3 pain, fever, fatigue, headache, chills, and muscle pain after a second dose of $\mathrm{BNT} 162 \mathrm{~b} 2$ is higher than $1 \%$ [59]. In the phase 3 clinical trial of mRNA-1273, 5.6\% and $19.5 \%$ of the subjects experienced grade 3 adverse reactions after the first and second doses, respectively [14]. Notably, four and six serious vaccine-related adverse reactions were encountered in the phase 3 clinical trials of BNT162b2 and mRNA1273 , respectively [14,15]. Pain, fever, chills, muscle ache, headache, and malaise were the most common adverse reactions in subjects who received adenoviral vector vaccines [17-19,54]. Prophylactic paracetamol can effectively reduce adverse reactions. In subjects receiving AZD1222 who did not use paracetamol, the incidences of grade 3 feverishness, chills, malaise, fatigue, and headache could exceed 5\% [44]. One vaccine-related severe adverse event (transverse myelitis) occurred in subjects who received AZD-1222 [18]. Seven serious adverse events were considered to be related to Ad26.COV2.S [19]. Inactivated vaccines have a good safety profile with few grade 3 adverse reactions, and two serious vaccine-related adverse events were considered to be related to CoronaVac, BBIBP-CorV, and COVXIN [20-22,25].

\section{Post-licensure evaluation}

Post-licensure safety surveillance allows the timely detection of rare or delayed adverse reactions and those that only occur in certain subgroups [60]. COVID-19 vaccine safety surveillance is critical for the rapid mass immunization campaigns implemented during the pandemic to detect potential safety problems early and thus implement corrective measures [61]. Cerebral venous and dural sinus thrombosis (CVST) with thrombocytopenia after vaccination with Ad26.COV2.S and ADZ-1222 were monitored by the Vaccine Adverse Event Reporting System (VAERS) in the US and the Pharmacovigilance Risk Assessment Committee in Europe [62,63]. The estimated incidence rate of CVST following AZD-1222 vaccination is 5.0 per million people in Europe [64]. Based on the US CDC, the incidence of thrombosis with 
thrombocytopenia syndrome is approximately 7 per 1 million Ad26.COV2.S vaccinated women between 18 and 49 years old [65]. The National Health Service of the UK recommends that people under the age of 40 years without other health conditions should not be administered with AZD-1222 [66]. The risk of thrombocytopenic, thromboembolic, and hemorrhagic events significantly increase after the first dose of AZD-1222 [67]. Two mRNA vaccines (BNT162b2 and mRNA-1273) are associated with the risk of anaphylaxis, delayed large local reactions [68-70], and the risk of myocarditis/pericarditis especially in adolescents [71]. The reported rates of anaphylaxis following BNT162b2 and mRNA-1273 vaccination were 4.7 and 2.5 per 1 million doses administered, respectively [72]. Post-vaccination myocarditis/pericarditis occurs mainly in young men, and the reported rate in males aged 12-17 years after the second dose of BNT162b2 or mRNA-1273 was 66.7 per million doses [71]. No serious adverse reactions of inactivated vaccines (BBIBP-CorV and WIV04) were observed in the large-scale safety surveillance after emergency use [73]. The medium- and long-term safety of the newly developed COVID-19 vaccines require ongoing evaluation.

\section{Vaccines versus new variants}

Multiple SARS-CoV-2 variants have emerged globally. Four variants, namely, Alpha (B.1.1.7), Beta (B.1.351), Gamma (P.1), and Delta (B.1.617.2), are classified as variants of concern (VOC) by the WHO. In addition to VOC, the other variants of interest (VOI) include Epsilon (B.1.429) and Iota (B.1.526), which were first detected in the United States, and many more [74].

As shown in Table 2, variants have varying degrees of resistance to neutralizing activity of serum from vaccinated individuals. The neutralization activity of vaccines against the Alpha variant shows little change [75-81]. The Beta variant is relatively more affected by the neutralization response induced by the vaccine with a 2- to 11-fold decrease $[75,76,78,79,81-85]$. The Gamma variant may be less resistant to vaccine-induced antibodies than the Beta variant but is more resistant than the Alpha variant $[75,81,86]$. The decrease in neutralization activity against the Delta variant may differ among different vaccines. The neutralization activity of the inactivated vaccine COVAXIN against the Delta variant decreased by 1.95 -fold [80]. For the mRNA-1273 and BNT162b2 vaccines, the neutralization activity could decrease by 1.4 - to 5.8 -fold [87-89]. The neutralization activity of AZD-1222 against the Delta variant decreased by 3.2-fold [90]. Limited Data are available on the immunization escape for the VOI. The neutralization activities of the mRNA-1273, NVXCoV2373, and CoronaVac vaccines against the Epsilon variant decreased by approximately 1 - to 2 -fold $[81,84]$.
The effect of neutralization against the Iota variant may be predominantly concentrated in the version carrying E484K [85].

The efficacy or effectiveness of AZD-1222, NVXCoV2373, Ad26.COV2.S, BNT162b2, mRNA-1273, COVAXIN, and CVnCoV against the COVID-19 variants has been reported. The efficacies of AZD-1222, NVXCOV2373, and $\mathrm{CVnCoV}$ against symptomatic cases caused by infection with the Alpha variant were $70.4 \%$ (95\% CI $43.6 \%-84.5 \%$ ) [91], $86.3 \%$ (95\% CI $71.3 \%-$ $93.5 \%$ ) [26], and $55 \%$ (95\% CI 24\%-74\%) [16], respectively (Table 2). In actual studies in Qatar, the effectiveness of BNT162b2 and mRNA-1273 against infection with the Alpha variant was $89.5 \%$ (95\% CI $85.9 \%-92.3 \%$ ) and $100 \%$ (95\% CI 91.8\%-100\%), respectively $[92,93]$. The efficacy of some vaccines against the Beta variant is significantly lower than that against the wild-type virus in clinical trials. The efficacies of AZD1222 and NVX-CoV2373 against the Beta variant were $10.4 \%$ (95\% CI $-76.8 \%$ to $54.8 \%$ ) [83] and $60.1 \%$ (95\% CI $19.9 \%-80.1 \%$ ) [94], respectively, which did not meet the WHO standard for COVID-19 vaccines [13]. The efficacy of Ad26.COV2.S in South Africa was $64.0 \%$ (95\% CI 41.2\%-78.7\%) against moderate-to-severe disease, similar to the result obtained in the United States [19]. The efficacies of BNT162b2 and mRNA-1273 against infection with the Beta variant in Qatar were 75.0\% (95\% CI $70.5 \%-78.9 \%$ ) and $96.4 \%$ (95\% CI 91.9\%-98.7\%), which were relatively lower than those obtained against the Alpha variant $[92,93]$. However, the effectiveness of BNT162b2 against the development of severe, critical, or fatal disease caused by infection with the Beta variant was $100.0 \%$ (95\% CI 73.7\%-100.0\%) [92]. The clinical trial of CVnCoV shows an efficacy of $67 \%$ (95\% CI 30\%-58\%) against symptomatic cases of infection with the Gamma variant [16]. A study in Manaus, Brazil showed that at least one dose of CoronaVac was associated with an effectiveness of $49.6 \%$ (95\% CI $11.3 \%-71.4 \%$ ) against symptomatic Gamma variant infection [95]. As for the Delta variant, a study in UK revealed that the efficacies of BNT162b2 and AZD-1222 against symptomatic diseases were $87.9 \%$ (95\% CI $78.2 \%-93.2 \%$ ) and $59.8 \%$ (95\% CI 28.9\%-77.3\%), respectively [35]. A clinical trial of COVAXIN in India also indicated that the efficacy against symptomatic diseases was $65.2 \%$ (95\% CI $33.1 \%-83.0 \%$ ) [21].

Notably, a comprehensive comparison of the neutralizing activity of the different variants may be difficult because of the differences in sample size, sample selection, and assay methods. For vaccines with large differences in neutralization activity against the original strains, even if the decrease in the neutralization activity against the mutant strains is similar, the ultimate level of effectiveness will still differ. Furthermore, the effectiveness of the vaccines against the variants is not only affected by 


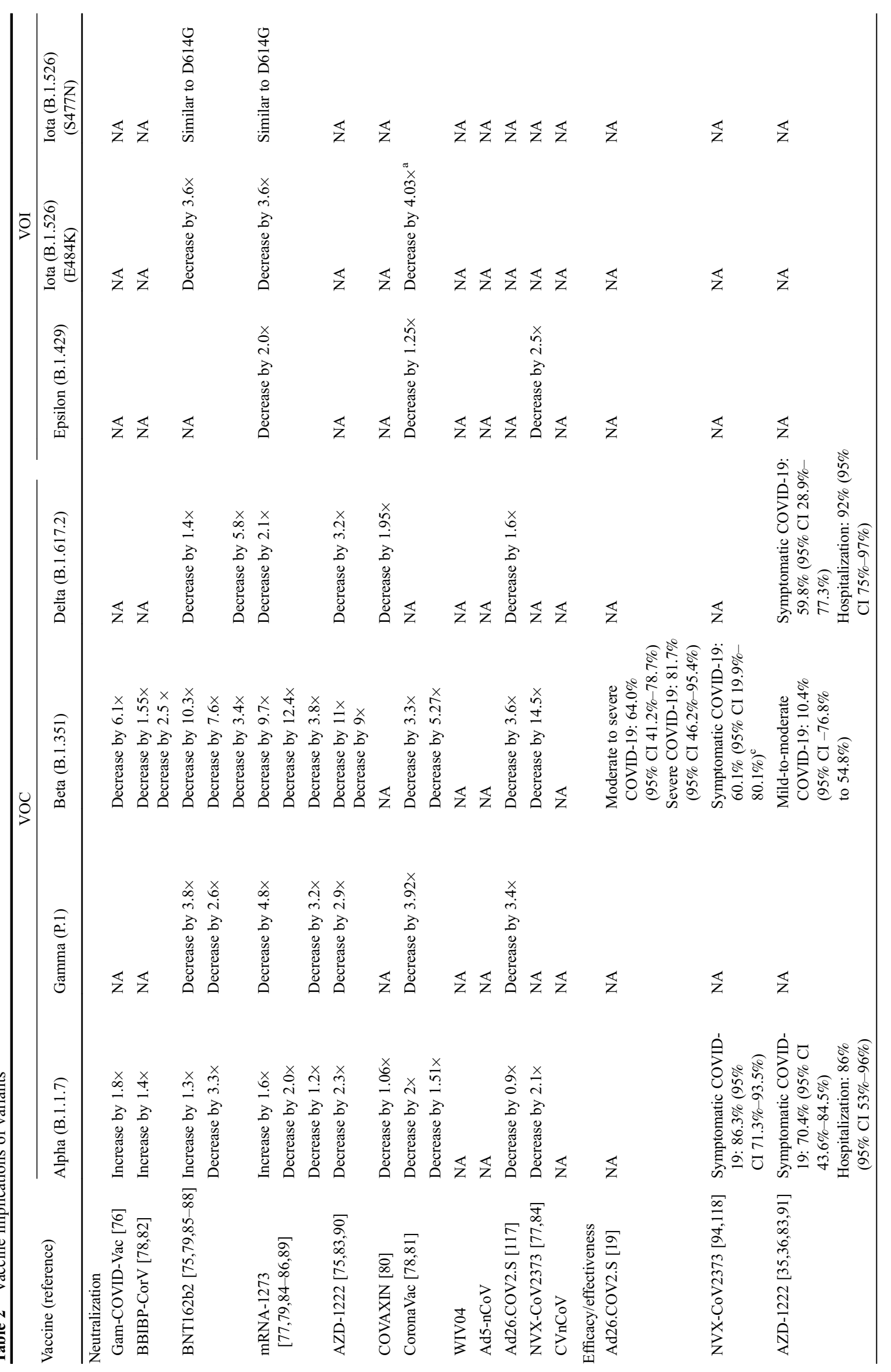


Zehong Huang et al.

47

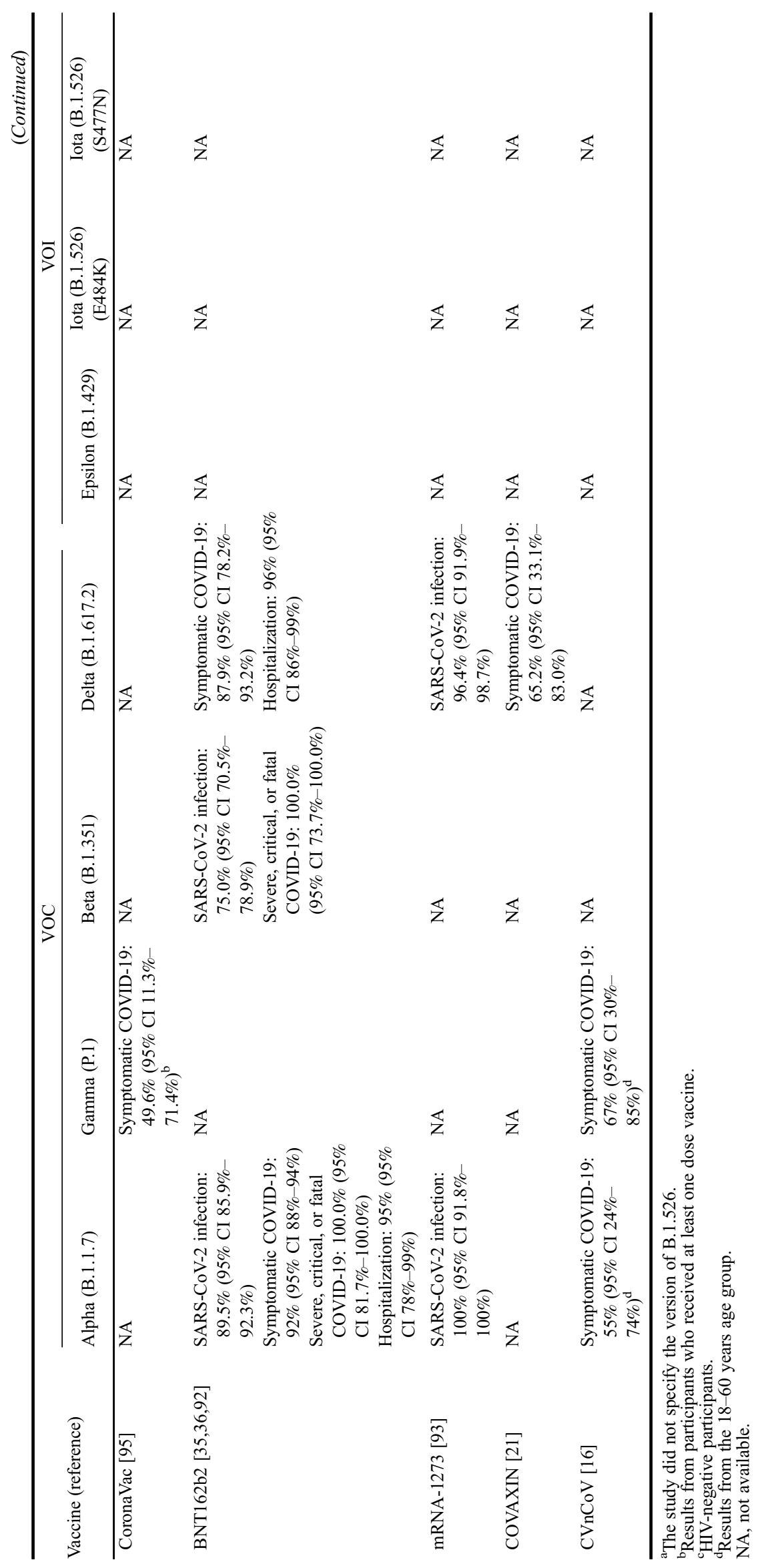


neutralization activity. In terms of immune response, the influence of variants on cellular immunity may also cause changes in vaccine effectiveness. The Y453F and L452R mutations result in HLA-A24-mediated cellular immune escape [96]. In addition, outside the immune response, the enhanced ability of the variants to bind to the receptor may also enhance the replication and infectivity than those of the wild-type strain, as observed in the Alpha and Delta variants [97]. This phenomenon could lead to more infections and resource limitations or strain placed on clinical care, thus affecting vaccine effectiveness. Cohort studies in the UK confirmed that the Alpha variant does not increase the risk of severe illness or death [98], which contradicted previous studies [99]; early cases were selected to exclude any substantial resource limitation or strain on clinical care. In combination with the current situation in India, these findings may suggest that the variants affect vaccine effectiveness through enhanced replication and transmission and not merely immune escape. Moreover, at the regional level, different levels of NPI implementation may also affect the protection afforded by vaccines.

\section{Challenges and perspectives}

Benefiting from the accumulation of knowledge about vaccines, parallel development based on multiple vaccine platforms, and unprecedented close collaboration among scientific research institutions, enterprises, governments, and regulatory agencies worldwide, COVID-19 vaccines have achieved rapid success in the initial stage, suggesting the possibility of future control over the pandemic. Most countries are scrambling to implement vaccination programs, as several vaccines have been approved for marketing or emergency use. However, achieving control over the pandemic is still hindered by many challenges. Global vaccine production and the rational distribution of the vaccines are major short-term issues. In addition, while attempting to improve the speed and capacity of vaccine development, issues such as approval policies for subsequent vaccines, surveillance of variant viruses, vaccine safety surveillance, and infrastructure for vaccine management and vaccination in low-income countries are also critical.

\section{Accelerated vaccination should be prioritized}

Globally, the access to and distribution and speed of vaccination are key factors in achieving herd immunity. As of May 16, 2021, 1.47 billion doses of COVID-19 vaccine had been administered globally [100]. Interestingly, in countries with high coverage rates such as Israel, the vaccine has shown good results in terms of controlling the pandemic, not only in the aspect preventing serious disease and death but also reducing infections [28]. In terms of limited vaccine supplies, some countries have adjusted immunization intervals to maximize vaccine coverage [101-103] to enhance the coverage of the vaccine and limit viral replication and infection and thus reduce viral mutations. Furthermore, the storage conditions of vaccines should be considered. Strict storage and transportation conditions may remarkably affect vaccine accessibility, especially in underdeveloped regions. At present, most vaccines such as inactivated, recombinant protein, and some adenovirus vector vaccines can be stored stably at 2$8^{\circ} \mathrm{C}$ (Table 1), and the more temperature-sensitive mRNA vaccine (BNT162b2 and mRNA-1273) are currently available store at $2-8{ }^{\circ} \mathrm{C}$ for one month $[104,105]$. The improvement of vaccine storage and transportation conditions is another key point in vaccine development. In addition, vaccination hesitancy or resistance negatively affects mass vaccination campaigns. Dealing with vaccine hesitancy is complex, and experts recommend comprehensive multi-component approaches tailored to the local population combined with good communication at the individual level $[106,107]$. Specific strategies for addressing vaccine hesitancy include offering tailored communication from trusted sources, improving access to vaccines, community engagement, and training and education activities [107]. In some strongly hesitant populations, health knowledge highlighting personal benefit may be more effective than emphasizing collective benefit [108].

\section{Escaped variants make pandemic control uncertain}

Variants that pose threats to pandemic control may enhance transmissibility and elude the immune response induced by a vaccine. The current VOCs include Alpha, Beta, Gamma, and Delta [74]. Beta variant, which was first discovered in South Africa, has shown the most significant capacity for immune escape, and some vaccine-induced neutralizing antibody titers decreased by up to 10 -fold $[79,83]$. AZD1222 and NVX-COV2373 are less efficacious in South Africa than in other regions, in which AZD-1222 has no significant protective effect against the Beta variant $[83,94]$. Notably, both vaccines showed decreased efficacy in terms of preventing symptomatic COVID-19 cases, although severe cases occurred in the placebo group and not in the vaccine group. Studies on BNT162b2 in Qatar have shown similar results, indicating that the vaccine may be less effective against infection with the Beta variant, but the effectiveness against severe disease remains extremely robust [92]. The effect of the variants, especially the variants with immune escape capacity, on vaccine efficacy is still controversial, and manufacturers and research institutions are considering different ways of addressing the situation. The development of vaccines against variants and intensive vaccination with the prototype strain vaccine 
are the key pandemic responses. The clinical immunogenicity results for the Moderna prototype vaccine and the variant vaccine in terms of enhancing immunity suggest the feasibility of this strategy [109]. However, the success of these two approaches are not guaranteed. The proliferation of variants and the time required to verify efficacy pose challenges for the development and implementation of variant vaccines. By contrast, the most rapid and effective way to deal with the current variants is the immediate vaccination of as many people as possible, creating an immune barrier that reduces the risk of mutation.

The extensive replication and transmission of the virus in hosts with low immunity may lead to more mutations, posing a greater challenge to vaccine effectiveness. In response to emerging variants, the US Food and Drug Administration (FDA) issued guidance in late February 2021 on how to evaluate the Emergency Use Authorization application for COVID-19 vaccine against emerging variants [110]. The FDA could accept Data from smaller clinical trials, similar to those for seasonal flu vaccines. This issuance could accelerate the review process for improved versions of vaccines, and its previous versions have exhibited acceptable safety and efficacy. A coalition of regulators from Australia, Canada, Singapore, Switzerland, the UK, and the European Union has issued similar guidelines [111-113]. If COVID-19 becomes endemic, vaccine updates could also follow a process similar to that for seasonal influenza vaccines.

In addition, research on new vaccines and vaccine immunization strategies to improve the broad spectrum of vaccine efficacy and convenience will also be focuses of future research.

\section{Medium-to-long-term safety and rare serious adverse events after vaccination need to be closely followed up}

The unprecedented speed and scale of vaccination against COVID-19 have magnified the safety risks of vaccines and even lead to unacceptable consequences for some vaccinated individuals. Adenovirus-vector vaccines AZD-1222 and Ad26.COV2.S did not cause serious adverse events in clinical trials, but CVST occurred after mass vaccination, arousing substantial concern worldwide $[62,63]$. Sample size and observation time constraints in clinical trials may cause medium-to-long-term and rare safety risks to be underrepresented. Therefore, after licensing, the medium-to-long-term safety of all types of vaccines should be followed up, and rare serious adverse events should be focused on.

\section{Conclusions}

Most of the current COVID-19 vaccines have shown satisfactory efficacy or effectiveness in actual clinical trials, suggesting that the pandemic can be controlled. However, some limitations are still encountered. More efforts are needed to facilitate rapid vaccine coverage, defense against variants capable of immune escape, and the surveillance of medium- and long-term safety risks and rare serious adverse events.

\section{Acknowledgements}

This work was supported by the National Natural Science Foundation of China (No. 81991491), the Fujian Natural Science Foundation for Distinguished Young Scholars (No. 2020J06007), and the Bill and Melinda Gates Foundation (No. INV-005834).

\section{Compliance with ethics guidelines}

Zehong Huang, Yingying Su, Tianying Zhang, and Ningshao Xia declare that they have no conflict of interest. This manuscript is a review article and does not involve a research protocol requiring approval by the relevant institutional review board or ethics committee.

\section{References}

1. World Health Organization. WHO coronavirus disease (COVID19) dashboard. 2021. https://covid19.who.int/ (accessed August 9, 2021)

2. Spinelli MA, Glidden DV, Gennatas ED, Bielecki M, Beyrer C, Rutherford G, Chambers H, Goosby E, Gandhi M. Importance of non-pharmaceutical interventions in lowering the viral inoculum to reduce susceptibility to infection by SARS-CoV-2 and potentially disease severity. Lancet Infect Dis 2021; 21(9): e296-e301

3. World Health Organization. Draft landscape of COVID-19 candidate vaccines. 2021. https://www.who.int/publications $/ \mathrm{m} /$ item/draft-landscape-of-covid-19-candidate-vaccines/ (accessed August 9, 2021)

4. National Medical Products Administration. Vaccine gets conditional approval for general use. 2021. http://subsites.chinadaily. com.cn/nmpa/2021-01/04/c_579626.htm (accessed August 9, 2021)

5. Sinovac. Sinovac receives conditional marketing authorization in China for its COVID-19 vaccine. 2021. http://www.sinovac.com. $\mathrm{cn} /$ news/shownews.php?id $=1153 \&$ lang $=$ en $($ accessed August 9, 2021)

6. National Medical Products Administration. NMPA conditionally approves COVID-19 vaccine developed by Sinopharm's Wuhan Institute. 2021. http://subsites.chinadaily.com.cn/nmpa/2021-02/ 27/c_597152.htm (accessed August 9, 2021)

7. CanSinoBIO. NMPA accepts the application for conditional marketing authorization of CanSinoBIO's COVID-19 vaccine Convidecia $^{\mathrm{TM}}$. 2021. http://www.cansinotech.com/html/1///179/ 180/651.html (accessed August 9, 2021)

8. U.S. Food and Drug Administration. Emergency use authorization. 2021. https://www.fda.gov/emergency-preparedness-and- 
response/mcm-legal-regulatory-and-policy-framework/emergencyuse-authorization\#vaccines (accessed August 9, 2021)

9. Medicines and Healthcare products Regulatory Agency. Regulatory approval of COVID-19 vaccine AstraZeneca. 2020. https:// www.gov.uk/government/publications/regulatory-approval-ofcovid-19-vaccine-astrazeneca (accessed August 9, 2021)

10. Milken Institute. Vaccines in use. 2021. https://www.covid19vaccinetracker.org/authorized-vaccines (accessed August 9, 2021)

11. Ministry of Health and Family Welfare, Government of India. Frequently asked questions - about the vaccine. 2021. https:// www.mohfw.gov.in/covid_vaccination/vaccination/faqs.html\#vaccine-registration (accessed August 9, 2021)

12. World Health Organization. Status of COVID-19 vaccines within WHO EUL/PQ evaluation process. 2021. https://extranet.who.int/ pqweb/sites/default/files/documents/Status_COVID_VAX_15July2021.pdf (accessed August 9, 2021)

13. World Health Organization. WHO target product profiles for COVID-19 vaccines. 2020. https://www.who.int/publications $/ \mathrm{m} /$ item/who-target-product-profiles-for-covid-19-vaccines/ (accessed August 9, 2021)

14. Baden LR, El Sahly HM, Essink B, Kotloff K, Frey S, Novak R, Diemert D, Spector SA, Rouphael N, Creech CB, McGettigan J, Khetan S, Segall N, Solis J, Brosz A, Fierro C, Schwartz H, Neuzil K, Corey L, Gilbert P, Janes H, Follmann D, Marovich M, Mascola J, Polakowski L, Ledgerwood J, Graham BS, Bennett H, Pajon R, Knightly C, Leav B, Deng W, Zhou H, Han S, Ivarsson M, Miller J, Zaks T; the COVE Study Group. Efficacy and Safety of the mRNA-1273 SARS-CoV-2 vaccine. N Engl J Med 2021; 384(5): 403-416

15. Polack FP, Thomas SJ, Kitchin N, Absalon J, Gurtman A, Lockhart S, Perez JL, Pérez Marc G, Moreira ED, Zerbini C, Bailey R, Swanson KA, Roychoudhury S, Koury K, Li P, Kalina WV, Cooper D, Frenck RW Jr, Hammitt LL, Türeci Ö, Nell H, Schaefer A, Ünal S, Tresnan DB, Mather S, Dormitzer PR, Şahin U, Jansen KU, Gruber WC; the C4591001 Clinical Trial Group. Safety and efficacy of the BNT162b2 mRNA Covid-19 vaccine. N Engl J Med 2020; 383(27): 2603-2615

16. CureVac. CureVac: final analysis of pivotal phase $2 b / 3$ HERALD Study. 2021. https://www.curevac.com/wp-content/uploads/2021/ 07/20210107_CureVac_Final-Analysis-of-Pivotal-Phase-2b3_Presentation_FINAL.pdf (accessed August 9, 2021)

17. Logunov DY, Dolzhikova IV, Shcheblyakov DV, Tukhvatulin AI, Zubkova OV, Dzharullaeva AS, Kovyrshina AV, Lubenets NL, Grousova DM, Erokhova AS, Botikov AG, Izhaeva FM, Popova O, Ozharovskaya TA, Esmagambetov IB, Favorskaya IA, Zrelkin DI, Voronina DV, Shcherbinin DN, Semikhin AS, Simakova YV, Tokarskaya EA, Egorova DA, Shmarov MM, Nikitenko NA, Gushchin VA, Smolyarchuk EA, Zyryanov SK, Borisevich SV, Naroditsky BS, Gintsburg AL; Gam-COVID-Vac Vaccine Trial Group.Safety and efficacy of an rAd26 and rAd5 vector-based heterologous prime-boost COVID-19 vaccine: an interim analysis of a randomised controlled phase 3 trial in Russia. Lancet 2021; 397(10275): 671-681

18. Voysey M, Clemens SAC, Madhi SA, Weckx LY, Folegatti PM, Aley PK, Angus B, Baillie VL, Barnabas SL, Bhorat QE, Bibi S, Briner C, Cicconi P, Collins AM, Colin-Jones R, Cutland CL, Darton TC, Dheda K, Duncan CJA, Emary KRW, Ewer KJ, Fairlie
L, Faust SN, Feng S, Ferreira DM, Finn A, Goodman AL, Green CM, Green CA, Heath PT, Hill C, Hill H, Hirsch I, Hodgson SHC, Izu A, Jackson S, Jenkin D, Joe CCD, Kerridge S, Koen A, Kwatra G, Lazarus R, Lawrie AM, Lelliott A, Libri V, Lillie PJ, Mallory R, Mendes AVA, Milan EP, Minassian AM, McGregor A, Morrison H, Mujadidi YF, Nana A, O'Reilly PJ, Padayachee SD, Pittella A, Plested E, Pollock KM, Ramasamy MN, Rhead S, Schwarzbold AV, Singh N, Smith A, Song R, Snape MD, Sprinz E, Sutherland RK, Tarrant R, Thomson EC, Török ME, Toshner M, Turner DPJ, Vekemans J, Villafana TL, Watson MEE, Williams CJ, Douglas AD, Hill AVS, Lambe T, Gilbert SC, Pollard AJ; Oxford COVID Vaccine Trial Group. Safety and efficacy of the ChAdOx1 nCoV19 vaccine (AZD1222) against SARS-CoV-2: an interim analysis of four randomised controlled trials in Brazil, South Africa, and the UK. Lancet 2021; 397(10269): 99-111

19. Sadoff J, Gray G, Vandebosch A, Cárdenas V, Shukarev G, Grinsztejn B, Goepfert PA, Truyers C, Fennema H, Spiessens B, Offergeld K, Scheper G, Taylor KL, Robb ML, Treanor J, Barouch DH, Stoddard J, Ryser MF, Marovich MA, Neuzil KM, Corey L, Cauwenberghs N, Tanner T, Hardt K, Ruiz-Guiñazú J, Le Gars M, Schuitemaker H, Van Hoof J, Struyf F, Douoguih M; ENSEMBLE Study Group. Safety and efficacy of single-dose Ad26.COV2.S vaccine against Covid-19. N Engl J Med 2021; 384(23): 21872201

20. Al Kaabi N, Zhang Y, Xia S, Yang Y, Al Qahtani MM, Abdulrazzaq N, Al Nusair M, Hassany M, Jawad JS, Abdalla J, Hussein SE, Al Mazrouei SK, Al Karam M, Li X, Yang X, Wang W, Lai B, Chen W, Huang S, Wang Q, Yang T, Liu Y, Ma R, Hussain ZM, Khan T, Saifuddin Fasihuddin M, You W, Xie Z, Zhao Y, Jiang Z, Zhao G, Zhang Y, Mahmoud S, ElTantawy I, Xiao P, Koshy A, Zaher WA, Wang H, Duan K, Pan A, Yang X. Effect of 2 inactivated SARS-CoV-2 vaccines on symptomatic COVID-19 infection in adults: a randomized clinical trial. JAMA 2021; 326(1): 35-45

21. Ella R, Reddy S, Blackwelder W, Potdar V, Yadav P, Sarangi V, Aileni VK, Kanungo S, Rai S, Reddy P, Verma S, Singh C, Redkar S, Mohapatra S, Pandey A, Ranganadin P, Gumashta R, Multani M, Mohammad S, Bhatt P, Kumari L, Sapkal G, Gupta N, Abraham P, Panda S, Prasad S, Bhargava B, Ella K, Vadrevu KM. Efficacy, safety, and lot to lot immunogenicity of an inactivated SARS-CoV-2 vaccine (BBV152): a double-blind, randomised, controlled phase 3 trial. medRxiv 2021: 2021.2006.2030. 21259439

22. Palacios R, Batista AP, Albuquerque CSN, Patiño EG, Santos JdP, Conde MTRP, Piorelli RdO, Júnior LCP, Raboni SM, Ramos F, Romero GAS, Leal FE, Camargo LFA, Aoki FH, Coelho EB, Oliveira DS, Fontes CJF, Pileggi GCS, Oliveira ALLd, Siqueira AMd, Oliveira DBLd, Botosso VF, Zeng G, Xin Q, Teixeira MM, Nogueira ML, Kallas EG. Efficacy and safety of a COVID-19 inactivated vaccine in healthcare professionals in Brazil: the PROFISCOV study. Preprint from SSRN. 2021. PPR: PPR341815

23. Sinovac. Summary of clinical trial Data of Sinovac's COVID-19 vaccine (CoronaVac $\left.{ }^{\circledR}\right)$. 2021. http://www.sinovac.com.cn/news/ shownews.php?id = 1154\&lang $=$ en $($ accessed August 9, 2021)

24. World Health Organization. Evidence assessment: Sinovac/CoronaVac COVID-19 vaccine. 2021. https://cdn.who.int/media/docs/ default-source/immunization/sage/2021/apri1/5_sage29apr2021_critical-evidence_sinovac.pdf?sfvrsn $=2488098 \mathrm{~d} \_5 \quad$ (accessed 
August 9, 2021)

25. Tanriover M D, Doğanay H L, Akova M, Güner H R, Azap A, Akhan S, Köse Ş, Erdinç F Ş, Akalın E H, Tabak Ö F, Pullukçu H, Batum Ö, Şimşek Yavuz S, Turhan Ö, Yıldırmak M T, Köksal İ, Taşova Y, Korten V, Yılmaz G, Çelen M K, Altın S, Çelik İ, Bayındır Y, Karaoğlan İ, Yılmaz A, Özkul A, Gür H, Unal S; CoronaVac Study Group. Efficacy and safety of an inactivated whole-virion SARS-CoV-2 vaccine (CoronaVac): interim results of a double-blind, randomised, placebo-controlled, phase 3 trial in Turkey. Lancet 2021; 398(10296): 213-222.

26. Heath PT, Galiza EP, Baxter DN, Boffito M, Browne D, Burns F, Chadwick DR, Clark R, Cosgrove C, Galloway J, Goodman AL, Heer A, Higham A, Iyengar S, Jamal A, Jeanes C, Kalra PA, Kyriakidou C, McAuley DF, Meyrick A, Minassian AM, Minton J, Moore P, Munsoor I, Nicholls H, Osanlou O, Packham J, Pretswell CH, San Francisco Ramos A, Saralaya D, Sheridan RP, Smith R, Soiza RL, Swift PA, Thomson EC, Turner J, Viljoen ME, Albert G, Cho I, Dubovsky F, Glenn G, Rivers J, Robertson A, Smith K, Toback S; 2019nCoV-302 Study Group. Safety and efficacy of NVX-CoV2373 Covid-19 vaccine. N Engl J Med 2021; 385(13): 1172-1183

27. Novavax. PREVENT-19 phase 3 trial Data factsheet. 2021. https:// wdet.org/media/wdet/assets/2021/06/17/Novavax-PREVENT-19Trial-Data-Factsheet-2021-06-14-v6-EN.pdf (accessed August 9, 2021)

28. Rossman H, Shilo S, Meir T, Gorfine M, Shalit U, Segal E. COVID-19 dynamics after a national immunization program in Israel. Nat Med 2021; 27(6): 1055-1061

29. Dagan N, Barda N, Kepten E, Miron O, Perchik S, Katz MA, Hernán MA, Lipsitch M, Reis B, Balicer RD. BNT162b2 mRNA Covid-19 vaccine in a nationwide mass vaccination setting. N Engl J Med 2021; 384(15): 1412-1423

30. Jara A, Undurraga EA, González C, Paredes F, Fontecilla T, Jara G, Pizarro A, Acevedo J, Leo K, Leon F, Sans C, Leighton P, Suárez $\mathrm{P}$, García-Escorza $\mathrm{H}$, Araos R. Effectiveness of an inactivated SARS-CoV-2 vaccine in Chile. N Engl J Med 2021; 385(10): 875-884

31. Corchado-Garcia J, Puyraimond-Zemmour D, Hughes T, CristeaPlaton T, Lenehan P, Pawlowski C, Bade S, O'Horo JC, Gores GJ, Williams AW, Badley AD, Halamka J, Virk A, Swift MD, Wagner T, Soundararajan V. Real-world effectiveness of Ad26.COV2.S adenoviral vector vaccine for COVID-19. medRxiv 2021: 2021.04.27.21256193

32. Thompson MG, Burgess JL, Naleway AL, Tyner HL, Yoon SK, Meece J, Olsho LEW, Caban-Martinez AJ, Fowlkes A, Lutrick K, Kuntz JL, Dunnigan K, Odean MJ, Hegmann KT, Stefanski E, Edwards LJ, Schaefer-Solle N, Grant L, Ellingson K, Groom HC, Zunie T, Thiese MS, Ivacic L, Wesley MG, Lamberte JM, Sun X, Smith ME, Phillips AL, Groover KD, Yoo YM, Gerald J, Brown RT, Herring MK, Joseph G, Beitel S, Morrill TC, Mak J, Rivers P, Harris KM, Hunt DR, Arvay ML, Kutty P, Fry AM, Gaglani M. Interim estimates of vaccine effectiveness of BNT162b2 and mRNA-1273 COVID-19 vaccines in preventing SARS-CoV-2 infection among health care personnel, first responders, and other essential and frontline workers - eight U.S. locations, December 2020-March 2021. MMWR Morb Mortal Wkly Rep 2021; 70(13): 495-500

33. Doherty M, Buchy P, Standaert B, Giaquinto C, Prado-Cohrs D.
Vaccine impact: benefits for human health. Vaccine 2016; 34(52): 6707-6714

34. Thompson MG, Burgess JL, Naleway AL, Tyner H, Yoon SK, Meece J, Olsho LEW, Caban-Martinez AJ, Fowlkes AL, Lutrick K, Groom HC, Dunnigan K, Odean MJ, Hegmann K, Stefanski E, Edwards LJ, Schaefer-Solle N, Grant L, Ellingson K, Kuntz JL, Zunie T, Thiese MS, Ivacic L, Wesley MG, Mayo Lamberte J, Sun $\mathrm{X}$, Smith ME, Phillips AL, Groover KD, Yoo YM, Gerald J, Brown RT, Herring MK, Joseph G, Beitel S, Morrill TC, Mak J, Rivers P, Poe BP, Lynch B, Zhou Y, Zhang J, Kelleher A, Li Y, Dickerson M, Hanson E, Guenther K, Tong S, Bateman A, Reisdorf E, Barnes J, Azziz-Baumgartner E, Hunt DR, Arvay ML, Kutty P, Fry AM, Gaglani M. Prevention and attenuation of Covid19 with the BNT162b2 and mRNA-1273 vaccines. N Engl J Med 2021; 385(4): 320-329

35. Bernal JL, Andrews N, Gower C, Gallagher E, Simmons R, Thelwall S, Stowe J, Tessier E, Groves N, Dabrera G, Myers R, Campbell C, Amirthalingam G, Edmunds M, Zambon M, Brown K, Hopkins S, Chand M, Ramsay M. Effectiveness of COVID-19 vaccines against the B.1.617.2 variant. medRxiv 2021: 2021.2005.2022.21257658

36. Public Health England. Vaccines highly effective against hospitalisation from Delta variant. 2021. https://www.gov.uk/government/ news/vaccines-highly-effective-against-hospitalisation-fromDelta-variant (accessed August 9, 2021)

37. Vasileiou E, Simpson CR, Shi T, Kerr S, Agrawal U, Akbari A, Bedston S, Beggs J, Bradley D, Chuter A, de Lusignan S, Docherty AB, Ford D, Hobbs FR, Joy M, Katikireddi SV, Marple J, McCowan C, McGagh D, McMenamin J, Moore E, Murray JL, Pan J, Ritchie L, Shah SA, Stock S, Torabi F, Tsang RS, Wood R, Woolhouse M, Robertson C, Sheikh A. Interim findings from firstdose mass COVID-19 vaccination roll-out and COVID-19 hospital admissions in Scotland: a national prospective cohort study. Lancet 2021; 397(10285): 1646-1657

38. WHO Ad Hoc Expert Group on the Next Steps for Covid-19 Vaccine Evaluation; Krause PR, Fleming TR, Longini IM, Peto R, Beral V, Bhargava B, Cravioto A, Cramer JP, Ellenberg SS, Figueroa JP, Halloran E, Henao-Restrepo AM, Ryan MJ, Levine MM, Nason M, Nohynek HM, Plotkin S, Rees H, Singh JA, Swaminathan S. Placebo-controlled trials of Covid-19 vaccineswhy we still need them. N Engl J Med 2021; 384(2): e2

39. Wendler D, Ochoa J, Millum J, Grady C, Taylor HA. COVID-19 vaccine trial ethics once we have efficacious vaccines. Science 2020; 370(6522): 1277-1279

40. Follmann D, Fintzi J, Fay MP, Janes HE, Baden LR, El Sahly HM, Fleming TR, Mehrotra DV, Carpp LN, Juraska M, Benkeser D, Donnell D, Fong Y, Han S, Hirsch I, Huang Y, Huang Y, Hyrien O, Luedtke A, Carone M, Nason M, Vandebosch A, Zhou H, Cho I, Gabriel E, Kublin JG, Cohen MS, Corey L, Gilbert PB, Neuzil KM. A deferred-vaccination design to assess durability of COVID19 vaccine effect after the placebo group is vaccinated. Ann Intern Med 2021; 174(8): 1118-1125

41. Jin P, Li J, Pan H, Wu Y, Zhu F. Immunological surrogate endpoints of COVID-2019 vaccines: the evidence we have versus the evidence we need. Signal Transduct Target Ther 2021; 6(1): 48

42. Anderson EJ, Rouphael NG, Widge AT, Jackson LA, Roberts PC, Makhene M, Chappell JD, Denison MR, Stevens LJ, Pruijssers AJ, 
McDermott AB, Flach B, Lin BC, Doria-Rose NA, O'Dell S, Schmidt SD, Corbett KS, Swanson PA 2nd, Padilla M, Neuzil KM, Bennett H, Leav B, Makowski M, Albert J, Cross K, Edara VV, Floyd K, Suthar MS, Martinez DR, Baric R, Buchanan W, Luke CJ, Phadke VK, Rostad CA, Ledgerwood JE, Graham BS, Beigel JH; mRNA-1273 Study Group. Safety and immunogenicity of SARS-CoV-2 mRNA-1273 vaccine in older adults. N Engl J Med 2020; 383(25): 2427-2438

43. Ella R, Reddy S, Jogdand H, Sarangi V, Ganneru B, Prasad S, Das D, Raju D, Praturi U, Sapkal G, Yadav P, Reddy P, Verma S, Singh C, Redkar SV, Gillurkar CS, Kushwaha JS, Mohapatra S, Bhate A, Rai S, Panda S, Abraham P, Gupta N, Ella K, Bhargava B, Vadrevu KM. Safety and immunogenicity of an inactivated SARS-CoV-2 vaccine, BBV152: interim results from a double-blind, randomised, multicentre, phase 2 trial, and 3-month follow-up of a double-blind, randomised phase 1 trial. Lancet Infect Dis 2021; 21 (7): 950-961

44. Folegatti PM, Ewer KJ, Aley PK, Angus B, Becker S, BelijRammerstorfer S, Bellamy D, Bibi S, Bittaye M, Clutterbuck EA, Dold C, Faust SN, Finn A, Flaxman AL, Hallis B, Heath P, Jenkin D, Lazarus R, Makinson R, Minassian AM, Pollock KM, Ramasamy M, Robinson H, Snape M, Tarrant R, Voysey M, Green C, Douglas AD, Hill AVS, Lambe T, Gilbert SC, Pollard AJ; Oxford COVID Vaccine Trial Group. Safety and immunogenicity of the ChAdOx1 nCoV-19 vaccine against SARS-CoV-2: a preliminary report of a phase $1 / 2$, single-blind, randomised controlled trial. Lancet 2020; 396(10249): 467-478

45. Formica N, Mallory R, Albert G, Robinson M, Plested JS, Cho I, Robertson A, Dubovsky F, Glenn GM. Evaluation of a SARSCoV-2 vaccine NVX-CoV2373 in younger and older adults. medRxiv 2021: 2021.2002.2026.21252482

46. Keech C, Albert G, Cho I, Robertson A, Reed P, Neal S, Plested JS, Zhu M, Cloney-Clark S, Zhou H, Smith G, Patel N, Frieman MB, Haupt RE, Logue J, McGrath M, Weston S, Piedra PA, Desai C, Callahan K, Lewis M, Price-Abbott P, Formica N, Shinde V, Fries L, Lickliter JD, Griffin P, Wilkinson B, Glenn GM. Phase 1-2 trial of a SARS-CoV-2 recombinant spike protein nanoparticle vaccine. N Engl J Med 2020; 383(24): 2320-2332

47. Logunov DY, Dolzhikova IV, Zubkova OV, Tukhvatullin AI, Shcheblyakov DV, Dzharullaeva AS, Grousova DM, Erokhova AS, Kovyrshina AV, Botikov AG, Izhaeva FM, Popova O, Ozharovskaya TA, Esmagambetov IB, Favorskaya IA, Zrelkin DI, Voronina DV, Shcherbinin DN, Semikhin AS, Simakova YV, Tokarskaya EA, Lubenets NL, Egorova DA, Shmarov MM, Nikitenko NA, Morozova LF, Smolyarchuk EA, Kryukov EV, Babira VF, Borisevich SV, Naroditsky BS, Gintsburg AL. Safety and immunogenicity of an $\operatorname{rAd} 26$ and $\operatorname{rAd} 5$ vector-based heterologous prime-boost COVID-19 vaccine in two formulations: two open, non-randomised phase $1 / 2$ studies from Russia. Lancet 2020; 396(10255): 887-897

48. Ramasamy MN, Minassian AM, Ewer KJ, Flaxman AL, Folegatti PM, Owens DR, Voysey M, Aley PK, Angus B, Babbage G, BelijRammerstorfer S, Berry L, Bibi S, Bittaye M, Cathie K, Chappell H, Charlton S, Cicconi P, Clutterbuck EA, Colin-Jones R, Dold C, Emary KRW, Fedosyuk S, Fuskova M, Gbesemete D, Green C, Hallis B, Hou MM, Jenkin D, Joe CCD, Kelly EJ, Kerridge S, Lawrie AM, Lelliott A, Lwin MN, Makinson R, Marchevsky NG, Mujadidi Y, Munro APS, Pacurar M, Plested E, Rand J, Rawlinson
T, Rhead S, Robinson H, Ritchie AJ, Ross-Russell AL, Saich S, Singh N, Smith CC, Snape MD, Song R, Tarrant R, Themistocleous Y, Thomas KM, Villafana TL, Warren SC, Watson MEE, Douglas AD, Hill AVS, Lambe T, Gilbert SC, Faust SN, Pollard AJ;Oxford COVID Vaccine Trial Group. Safety and immunogenicity of ChAdOx1 nCoV-19 vaccine administered in a prime-boost regimen in young and old adults (COV002): a single-blind, randomised, controlled, phase 2/3 trial. Lancet 2021; 396(10267): 1979-1993

49. Sadoff J, Le Gars M, Shukarev G, Heerwegh D, Truyers C, de Groot AM, Stoop J, Tete S, Van Damme W, Leroux-Roels I, Berghmans PJ, Kimmel M, Van Damme P, de Hoon J, Smith W, Stephenson KE, De Rosa SC, Cohen KW, McElrath MJ, Cormier E, Scheper G, Barouch DH, Hendriks J, Struyf F, Douoguih M, Van Hoof J, Schuitemaker H. Interim results of a phase 1-2a trial of Ad26.COV2.S Covid-19 vaccine. N Engl J Med 2021; 384(19): 1824-1835

50. Walsh EE, Frenck RW Jr, Falsey AR, Kitchin N, Absalon J, Gurtman A, Lockhart S, Neuzil K, Mulligan MJ, Bailey R, Swanson KA, Li P, Koury K, Kalina W, Cooper D, Fontes-Garfias C, Shi PY, Türeci Ö, Tompkins KR, Lyke KE, Raabe V, Dormitzer PR, Jansen KU, Şahin U, Gruber WC. Safety and immunogenicity of two RNA-based Covid-19 vaccine candidates. N Engl J Med 2020; 383(25): 2439-2450

51. Xia S, Duan K, Zhang Y, Zhao D, Zhang H, Xie Z, Li X, Peng C, Zhang Y, Zhang W, Yang Y, Chen W, Gao X, You W, Wang X, Wang Z, Shi Z, Wang Y, Yang X, Zhang L, Huang L, Wang Q, Lu J, Yang Y, Guo J, Zhou W, Wan X, Wu C, Wang W, Huang S, Du J, Meng Z, Pan A, Yuan Z, Shen S, Guo W, Yang X. Effect of an inactivated vaccine against SARS-CoV-2 on safety and immunogenicity outcomes: interim analysis of 2 randomized clinical trials. JAMA 2020; 324(10): 951-960

52. Xia S, Zhang Y, Wang Y, Wang H, Yang Y, Gao GF, Tan W, Wu G, Xu M, Lou Z, Huang W, Xu W, Huang B, Wang H, Wang W, Zhang W, Li N, Xie Z, Ding L, You W, Zhao Y, Yang X, Liu Y, Wang Q, Huang L, Yang Y, Xu G, Luo B, Wang W, Liu P, Guo W, Yang X. Safety and immunogenicity of an inactivated SARS-CoV2 vaccine, BBIBP-CorV: a randomised, double-blind, placebocontrolled, phase 1/2 trial. Lancet Infect Dis 2021; 21(1): 39-51

53. Zhang Y, Zeng G, Pan H, Li C, Hu Y, Chu K, Han W, Chen Z, Tang R, Yin W, Chen X, Hu Y, Liu X, Jiang C, Li J, Yang M, Song Y, Wang X, Gao Q, Zhu F. Safety, tolerability, and immunogenicity of an inactivated SARS-CoV-2 vaccine in healthy adults aged 18-59 years: a randomised, double-blind, placebo-controlled, phase 1/2 clinical trial. Lancet Infect Dis 2021; 21(2): 181-192

54. Zhu FC, Guan XH, Li YH, Huang JY, Jiang T, Hou LH, Li JX, Yang BF, Wang L, Wang WJ, Wu SP, Wang Z, Wu XH, Xu JJ, Zhang Z, Jia SY, Wang BS, Hu Y, Liu JJ, Zhang J, Qian XA, Li Q, Pan HX, Jiang HD, Deng P, Gou JB, Wang XW, Wang XH, Chen W. Immunogenicity and safety of a recombinant adenovirus type5 -vectored COVID-19 vaccine in healthy adults aged 18 years or older: a randomised, double-blind, placebo-controlled, phase 2 trial. Lancet 2020; 396(10249): 479-488

55. Kremsner P, Mann P, Bosch J, Fendel R, Gabor JJ, Kreidenweiss A, Kroidl A, Leroux-Roels I, Leroux-Roels G, Schindler C, Schunk M, Velavan TP, Fotin-Mleczek M, Müller S, Quintini G, Schönborn-Kellenberger O, Vahrenhorst D, Verstraeten T, Walz L, Wolz OO, Oostvogels L. Phase 1 assessment of the safety and 
immunogenicity of an mRNA-lipid nanoparticle vaccine candidate against SARS-CoV-2 in human volunteers. medRxiv 2020: 2020.2011.2009.20228551

56. Jeyanathan M, Afkhami S, Smaill F, Miller MS, Lichty BD, Xing Z. Immunological considerations for COVID-19 vaccine strategies. Nat Rev Immunol 2020; 20(10): 615-632

57. Sahin U, Muik A, Vogler I, Derhovanessian E, Kranz LM, Vormehr M, Quandt J, Bidmon N, Ulges A, Baum A, Pascal K, Maurus D, Brachtendorf S, Lörks V, Sikorski J, Koch P, Hilker R, Becker D, Eller AK, Grützner J, Tonigold M, Boesler C, Rosenbaum C, Heesen L, Kühnle MC, Poran A, Dong JZ, Luxemburger U, Kemmer-Brück A, Langer D, Bexon M, Bolte S, Palanche T, Schultz A, Baumann S, Mahiny AJ, Boros G, Reinholz J, Szabó GT, Karikó K, Shi PY, Fontes-Garfias C, Perez JL, Cutler M, Cooper D, Kyratsous CA, Dormitzer PR, Jansen KU, Türeci Ö. BNT162b2 induces SARS-CoV-2-neutralising antibodies and T cells in humans. medRxiv 2020: 2020.2012.2009.20245175

58. Jackson LA, Anderson EJ, Rouphael NG, Roberts PC, Makhene M, Coler RN, McCullough MP, Chappell JD, Denison MR, Stevens LJ, Pruijssers AJ, McDermott A, Flach B, Doria-Rose NA, Corbett KS, Morabito KM, O'Dell S, Schmidt SD, Swanson PA 2nd, Padilla M, Mascola JR, Neuzil KM, Bennett H, Sun W, Peters E, Makowski M, Albert J, Cross K, Buchanan W, Pikaart-Tautges R, Ledgerwood JE, Graham BS, Beigel JH; mRNA-1273 Study Group. An mRNA vaccine against SARS-CoV-2 - preliminary report. N Engl J Med 2020; 383(20): 1920-1931

59. FDA. Vaccines and Related Biological Products Advisory Committee Meeting, December 10, 2020, FDA Briefing Document. 2020. https://www.fda.gov/media/144245/download (accessed August 9, 2021)

60. Plotkin S, Orenstein W, Offit P, Edwards KM. Plotkin's Vaccines. Elsevier, 2017

61. Pless RP, Bentsi-Enchill AD, Duclos P. Monitoring vaccine safety during measles mass immunization campaigns: clinical and programmatic issues. J Infect Dis 2003; 187(Suppl 1): S291-S298

62. See I, Su JR, Lale A, Woo EJ, Guh AY, Shimabukuro TT, Streiff MB, Rao AK, Wheeler AP, Beavers SF, Durbin AP, Edwards K, Miller E, Harrington TA, Mba-Jonas A, Nair N, Nguyen DT, Talaat KR, Urrutia VC, Walker SC, Creech CB, Clark TA, DeStefano F, Broder KR. US case reports of cerebral venous sinus thrombosis with thrombocytopenia after Ad26.COV2.S vaccination, March 2 to April 21, 2021. JAMA 2021; 325(24): 2448-2456

63. Scully M, Singh D, Lown R, Poles A, Solomon T, Levi M, Goldblatt D, Kotoucek P, Thomas W, Lester W. Pathologic antibodies to platelet factor 4 after ChAdOx $1 \mathrm{nCoV}-19$ vaccination. N Engl J Med 2021; 384(23): 2202-2211

64. Lai CC, Ko WC, Chen CJ, Chen PY, Huang YC, Lee PI, Hsueh PR. COVID-19 vaccines and thrombosis with thrombocytopenia syndrome. Expert Rev Vaccines 2021; 20(8): 1027-1035

65. Centers for Disease Control and Prevention. Johnson \& Johnson's Janssen COVID-19 vaccine overview and safety. 2021. https:// www.cdc.gov/coronavirus/2019-ncov/vaccines/different-vaccines/ janssen.html (accessed August 9, 2021)

66. National Health Service. Coronavirus (COVID-19) vaccines side effects and safety. 2021. https://www.nhs.uk/conditions/coronavirus-covid-19/coronavirus-vaccination/safety-and-side-effects/ (accessed August 9, 2021)
67. Simpson CR, Shi T, Vasileiou E, Katikireddi SV, Kerr S, Moore E, McCowan C, Agrawal U, Shah SA, Ritchie LD, Murray J, Pan J, Bradley DT, Stock SJ, Wood R, Chuter A, Beggs J, Stagg HR, Joy M, Tsang RSM, de Lusignan S, Hobbs R, Lyons RA, Torabi F, Bedston S, O'Leary M, Akbari A, McMenamin J, Robertson C, Sheikh A. First-dose ChAdOx1 and BNT162b2 COVID-19 vaccines and thrombocytopenic, thromboembolic and hemorrhagic events in Scotland. Nat Med 2021; 27(7): 1290-1297

68. Blumenthal KG, Freeman EE, Saff RR, Robinson LB, Wolfson AR, Foreman RK, Hashimoto D, Banerji A, Li L, Anvari S, Shenoy ES. Delayed large local reactions to mRNA-1273 vaccine against SARS-CoV-2. N Engl J Med 2021; 384(13): 1273-1277

69. Kelso JM. Anaphylactic reactions to novel mRNA SARS-CoV-2/ COVID-19 vaccines. Vaccine 2021; 39(6): 865-867

70. Baeck M, Marot L, Belkhir L. Delayed large local reactions to mRNA vaccines. N Engl J Med 2021; 384(24): e98

71. Centers for Disease Control and Prevention. Use of mRNA COVID-19 vaccine after reports of myocarditis among vaccine recipients: update from the Advisory Committee on Immunization Practices - United States, June 2021. 2021. https://www.cdc.gov/ mmwr/volumes/70/wr/mm7027e2.htm (accessed August 9, 2021)

72. Shimabukuro TT, Cole M, Su JR. Reports of anaphylaxis after receipt of mRNA COVID-19 vaccines in the US-December 14, 2020-January 18, 2021. JAMA 2021; 325(11): 1101-1102

73. Yang ZN, Zhao YY, Li L, Gao HD, Cai Q, Sun XX, Zhang FS, Su JF, Zhang YN, Shu X, Wang XW, Yang YK, Zhang YT, Zhou S, Yang XM. Evaluation of safety of two inactivated COVID-19 vaccines in a large-scale emergency use. Chin J Epidemiol (Zhonghua Liu Xing Bing Xue Za Zhi) 2021; 42(6): 977-982 (in Chinese)

74. World Health Organization. Tracking SARS-CoV-2 variants. 2021. https://www.who.int/en/activities/tracking-SARS-CoV-2-variants/ (accessed August 9, 2021)

75. Dejnirattisai W, Zhou D, Supasa P, Liu C, Mentzer AJ, Ginn HM, Zhao Y, Duyvesteyn HME, Tuekprakhon A, Nutalai R, Wang B, López-Camacho C, Slon-Campos J, Walter TS, Skelly D, Costa Clemens SA, Naveca FG, Nascimento V, Nascimento F, Fernandes da Costa C, Resende PC, Pauvolid-Correa A, Siqueira MM, Dold C, Levin R, Dong T, Pollard AJ, Knight JC, Crook D, Lambe T, Clutterbuck E, Bibi S, Flaxman A, Bittaye M, BelijRammerstorfer S, Gilbert SC, Carroll MW, Klenerman P, Barnes E, Dunachie SJ, Paterson NG, Williams MA, Hall DR, Hulswit RJG, Bowden TA, Fry EE, Mongkolsapaya J, Ren J, Stuart DI, Screaton GR. Antibody evasion by the P.1 strain of SARS-CoV-2. Cell 2021; 184(11): 2939-2954.e9

76. Ikegame S, Siddiquey MNA, Hung CT, Haas G, Brambilla L, Oguntuyo KY, Kowdle S, Vilardo AE, Edelstein A, Perandones C, Kamil JP, Lee B. Qualitatively distinct modes of Sputnik V vaccine-neutralization escape by SARS-CoV-2 Spike variants. medRxiv 2021: 2021.2003.2031.21254660

77. Shen X, Tang H, McDanal C, Wagh K, Fischer W, Theiler J, Yoon H, Li D, Haynes BF, Sanders KO, Gnanakaran S, Hengartner N, Pajon R, Smith G, Glenn GM, Korber B, Montefiori DC. SARS$\mathrm{CoV}-2$ variant B.1.1.7 is susceptible to neutralizing antibodies elicited by ancestral spike vaccines. Cell Host Microbe 2021; 29 (4): 529-539.e3

78. Wang GL, Wang ZY, Duan LJ, Meng QC, Jiang MD, Cao J, Yao L, 
Zhu KL, Cao WC, Ma MJ. Susceptibility of circulating SARSCoV-2 variants to neutralization. N Engl J Med 2021; 384(24): 2354-2356

79. Wang P, Nair MS, Liu L, Iketani S, Luo Y, Guo Y, Wang M, Yu J, Zhang B, Kwong PD, Graham BS, Mascola JR, Chang JY, Yin MT, Sobieszczyk M, Kyratsous CA, Shapiro L, Sheng Z, Huang Y, Ho DD. Antibody resistance of SARS-CoV-2 variants B.1.351 and B.1.1.7. Nature 2021; 593(7857): 130-135

80. Yadav PD, Sapkal GN, Abraham P, Ella R, Deshpande G, Patil DY, Nyayanit DA, Gupta N, Sahay RR, Shete AM, Panda S, Bhargava B, Mohan VK. Neutralization of variant under investigation B.1.617 with sera of BBV152 vaccinees. bioRxiv 2021: 2021.2004.2023.441101

81. Chen Y, Shen H, Huang R, Tong X, Wu C. Serum neutralising activity against SARS-CoV-2 variants elicited by CoronaVac. Lancet Infect Dis 2021; 21(8): 1071-1072

82. Huang B, Dai L, Wang H, Hu Z, Yang X, Tan W, Gao GF. Serum sample neutralisation of BBIBP-CorV and ZF2001 vaccines to SARS-CoV-2 501Y.V2. Lancet Microbe 2021; 2(7): e285

83. Madhi SA, Baillie V, Cutland CL, Voysey M, Koen AL, Fairlie L, Padayachee SD, Dheda K, Barnabas SL, Bhorat QE, Briner C, Kwatra G, Ahmed K, Aley P, Bhikha S, Bhiman JN, Bhorat AE, du Plessis J, Esmail A, Groenewald M, Horne E, Hwa SH, Jose A, Lambe T, Laubscher M, Malahleha M, Masenya M, Masilela M, McKenzie S, Molapo K, Moultrie A, Oelofse S, Patel F, Pillay S, Rhead S, Rodel H, Rossouw L, Taoushanis C, Tegally H, Thombrayil A, van Eck S, Wibmer CK, Durham NM, Kelly EJ, Villafana TL, Gilbert S, Pollard AJ, de Oliveira T, Moore PL, Sigal A, Izu A; NGS-SA Group; Wits-VIDA COVID Group. Efficacy of the ChAdOx1 nCoV-19 Covid-19 vaccine against the B.1.351 variant. N Engl J Med 2021; 384(20): 1885-1898

84. Shen X, Tang H, Pajon R, Smith G, Glenn GM, Shi W, Korber B, Montefiori DC. Neutralization of SARS-CoV-2 variants B.1.429 and B.1.351. N Engl J Med 2021; 384(24): 2352-2354

85. Zhou H, Dcosta BM, Samanovic MI, Mulligan MJ, Landau NR, Tada T. B.1.526 SARS-CoV-2 variants identified in New York City are neutralized by vaccine-elicited and therapeutic monoclonal antibodies. mBio 2021; 12(4): e0138621

86. Wang P, Casner RG, Nair MS, Wang M, Yu J, Cerutti G, Liu L, Kwong PD, Huang Y, Shapiro L, Ho DD. Increased resistance of SARS-CoV-2 variant P.1 to antibody neutralization. Cell Host Microbe 2021; 29(5): 747-751.e4

87. Liu J, Liu Y, Xia H, Zou J, Weaver SC, Swanson KA, Cai H, Cutler M, Cooper D, Muik A, Jansen KU, Sahin U, Xie X, Dormitzer PR, Shi PY. BNT162b2-elicited neutralization of B.1.617 and other SARS-CoV-2 variants. Nature 2021; 596(7871): 273-275

88. Wall EC, Wu M, Harvey R, Kelly G, Warchal S, Sawyer C, Daniels R, Hobson P, Hatipoglu E, Ngai Y, Hussain S, Nicod J, Goldstone R, Ambrose K, Hindmarsh S, Beale R, Riddell A, Gamblin S, Howell M, Kassiotis G, Libri V, Williams B, Swanton C, Gandhi $\mathrm{S}$, Bauer DLV. Neutralising antibody activity against SARS-CoV-2 VOCs B.1.617.2 and B.1.351 by BNT162b2 vaccination. Lancet 2021; 397(10292): 2331-2333

89. Choi A, Koch M, Wu K, Dixon G, Oestreicher J, Legault H, Stewart-Jones GBE, Colpitts T, Pajon R, Bennett H, Carfi A, Edwards DK. Serum neutralizing activity of mRNA-1273 against SARS-CoV-2 variants. J Virol 2021; 95(23): e0131321

90. Sapkal GN, Yadav PD, Sahay RR, Deshpande G, Gupta N,
Nyayanit DA, Patil DY, Shete AM, Kumar S, Abraham P, Panda S, Bhargava B. Neutralization of Delta variant with sera of Covishield $^{\mathrm{TM}}$ vaccinees and COVID-19 recovered vaccinated individuals. J Travel Med 2021; 28(7): taab119

91. Emary KRW, Golubchik T, Aley PK, Ariani CV, Angus B, Bibi S, Blane B, Bonsall D, Cicconi P, Charlton S, Clutterbuck EA, Collins AM, Cox T, Darton TC, Dold C, Douglas AD, Duncan CJA, Ewer KJ, Flaxman AL, Faust SN, Ferreira DM, Feng S, Finn A, Folegatti PM, Fuskova M, Galiza E, Goodman AL, Green CM, Green CA, Greenland M, Hallis B, Heath PT, Hay J, Hill HC, Jenkin D, Kerridge S, Lazarus R, Libri V, Lillie PJ, Ludden C, Marchevsky NG, Minassian AM, McGregor AC, Mujadidi YF, Phillips DJ, Plested E, Pollock KM, Robinson H, Smith A, Song R, Snape MD, Sutherland RK, Thomson EC, Toshner M, Turner DPJ, Vekemans J, Villafana TL, Williams CJ, Hill AVS, Lambe T, Gilbert SC, Voysey M, Ramasamy MN, Pollard AJ; COVID-19 Genomics UK consortium; AMPHEUS Project; Oxford COVID19 Vaccine Trial Group. Efficacy of ChAdOx1 nCoV-19 (AZD1222) vaccine against SARS-CoV-2 variant of concern 202012/01 (B.1.1.7): an exploratory analysis of a randomised controlled trial. Lancet 2021; 397(10282): 1351-1362

92. Abu-Raddad LJ, Chemaitelly H, Butt AA; National Study Group for COVID-19 Vaccination. Effectiveness of the BNT162b2 Covid-19 vaccine against the B.1.1.7 and B.1.351 variants. N Engl J Med 2021; 385(2): 187-189

93. Chemaitelly H, Yassine HM, Benslimane FM, Al Khatib HA, Tang P, Hasan MR, Malek JA, Coyle P, Ayoub HH, Al Kanaani Z, Al Kuwari E, Jeremijenko A, Kaleeckal AH, Latif AN, Shaik RM, Abdul Rahim HF, Nasrallah GK, Al Kuwari MG, Al Romaihi HE, Al-Thani MH, Al Khal A, Butt AA, Bertollini R, Abu-Raddad LJ. mRNA-1273 COVID-19 vaccine effectiveness against the B.1.1.7 and B.1.351 variants and severe COVID-19 disease in Qatar. Nat Med 2021; 27(9): 1614-1621

94. Shinde V, Bhikha S, Hoosain Z, Archary M, Bhorat Q, Fairlie L, Lalloo U, Masilela MSL, Moodley D, Hanley S, Fouche L, Louw C, Tameris M, Singh N, Goga A, Dheda K, Grobbelaar C, Kruger G, Carrim-Ganey N, Baillie V, de Oliveira T, Lombard Koen A, Lombaard JJ, Mngqibisa R, Bhorat AE, Benadé G, Lalloo N, Pitsi A, Vollgraaff PL, Luabeya A, Esmail A, Petrick FG, Oommen-Jose A, Foulkes S, Ahmed K, Thombrayil A, Fries L, Cloney-Clark S, Zhu M, Bennett C, Albert G, Faust E, Plested JS, Robertson A, Neal S, Cho I, Glenn GM, Dubovsky F, Madhi SA; 2019nCoV-501 Study Group. Efficacy of NVX-CoV2373 Covid-19 Vaccine against the B.1.351 Variant. N Engl J Med 2021; 384(20): 1899 1909

95. Hitchings MDT, Ranzani OT, Torres MSS, de Oliveira SB, Almiron M, Said R, Borg R, Schulz WL, de Oliveira RD, da Silva PV, de Castro DB, Sampaio VS, de Albuquerque BC, Ramos TCA, Fraxe SHH, da Costa CF, Naveca FG, Siqueira AM, de Araújo WN, Andrews JR, Cummings DAT, Ko AI, Croda J. Effectiveness of CoronaVac among healthcare workers in the setting of high SARS-CoV-2 Gamma variant transmission in Manaus, Brazil: a test-negative case-control study. Lancet Reg Health Am 2021; 1: 100025

96. Motozono C, Toyoda M, Zahradnik J, Saito A, Nasser H, Tan TS, Ngare I, Kimura I, Uriu K, Kosugi Y, Yue Y, Shimizu R, Ito J, Torii S, Yonekawa A, Shimono N, Nagasaki Y, Minami R, Toya T, Sekiya N, Fukuhara T, Matsuura Y, Schreiber G, Genotype to 
Phenotype Japan (G2P-Japan) Consortium; Ikeda T, Nakagawa S, Ueno T, Sato K. SARS-CoV-2 spike L452R variant evades cellular immunity and increases infectivity. Cell Host Microbe 2021; 29(7): 1124-1136.e11

97. Kumar V, Singh J, Hasnain SE, Sundar D. Possible link between higher transmissibility of B.1.617 and B.1.1.7 variants of SARSCoV-2 and increased structural stability of its spike protein and hACE2 affinity. bioRxiv 2021: 2021.2004.2029.441933

98. Frampton D, Rampling T, Cross A, Bailey H, Heaney J, Byott M, Scott R, Sconza R, Price J, Margaritis M, Bergstrom M, Spyer MJ, Miralhes PB, Grant P, Kirk S, Valerio C, Mangera Z, Prabhahar T, Moreno-Cuesta J, Arulkumaran N, Singer M, Shin GY, Sanchez E, Paraskevopoulou SM, Pillay D, McKendry RA, Mirfenderesky M, Houlihan CF, Nastouli E. Genomic characteristics and clinical effect of the emergent SARS-CoV-2 B.1.1.7 lineage in London, UK: a whole-genome sequencing and hospital-based cohort study. Lancet Infect Dis 2021; 21(9): 1246-1256

99. Davies NG, Jarvis CI, CMMID COVID-19 Working Group; Edmunds WJ, Jewell NP, Diaz-Ordaz K, Keogh RH. Increased mortality in community-tested cases of SARS-CoV-2 lineage B.1.1.7. Nature 2021; 593(7858): 270-274

100. Our World in Data. COVID-19 vaccine doses administered, May 16, 2021. 2021. https://ourworldinData.org/grapher/cumulativecovid-vaccinations $?$ time $=$ latest $\&$ country $=\sim$ OWID_WRL (accessed August 9, 2021)

101. abc NEWS. Canada vaccine panel recommends 4 months between COVID doses. 2021. https://abcnews.go.com/International/wireStory/canada-vaccine-panel-recommends-months-covid-doses76239947 (accessed August 9, 2021)

102. National Health Service. Letter to chief executives of all NHS trusts and foundation trusts. 2020. https://www.england.nhs.uk/ coronavirus/wp-content/uploads/sites/52/2020/12/C0994-Systemletter-COVID-19-vaccination-deployment-planning-30-December-2020.pdf (accessed August 9, 2021)

103. Republic World. Turkey to extend interval between doses of the vaccine. 2021. https://www.republicworld.com/world-news/restof-the-world-news/turkey-to-extend-interval-between-doses-ofthe-vaccine.html (accessed August 9, 2021)

104. Moderna. Storing vaccine vials. 2021. https://www.modernatx. com/covid19vaccine-eua/providers/storage-handling (accessed August 9, 2021)

105. Precision Vaccinations. BioNTech-Pfizer COVID-19 vaccine. 2021. https://www.precisionvaccinations.com/vaccines/biontechpfizer-covid-19-vaccine (accessed August 9, 2021)

106. Jarrett C, Wilson R, O'Leary M, Eckersberger E, Larson HJ; SAGE Working Group on Vaccine Hesitancy. Strategies for addressing vaccine hesitancy - a systematic review. Vaccine 2015; 33(34): 4180-4190

107. Razai MS, Chaudhry UAR, Doerholt K, Bauld L, Majeed A. Covid-19 vaccination hesitancy. BMJ 2021; 373(1138): n1138

108. Freeman D, Loe BS, Yu LM, Freeman J, Chadwick A, Vaccari C, Shanyinde M, Harris V, Waite F, Rosebrock L, Petit A, Vanderslott S, Lewandowsky S, Larkin M, Innocenti S, Pollard AJ, McShane $\mathrm{H}$, Lambe S. Effects of different types of written vaccination information on COVID-19 vaccine hesitancy in the UK (OCEANS-III): a single-blind, parallel-group, randomised controlled trial. Lancet Public Health 2021; 6(6): e416-e427

109. Wu K, Choi A, Koch M, Ma L, Hill A, Nunna N, Huang W, Oestreicher J, Colpitts T, Bennett H, Legault H, Paila Y, Nestorova B, Ding B, Pajon R, Miller JM, Leav B, Carfi A, McPhee R, Edwards DK. Preliminary analysis of safety and immunogenicity of a SARS-CoV-2 variant vaccine booster. medRxiv 2021: 2021.2005.2005.21256716

110. U.S. Food and Drug Administration. Emergency use authorization for vaccines to prevent COVID-19. 2021. https://www.fda.gov/ regulatory-information/search-fda-guidance-documents/emergency-use-authorization-vaccines-prevent-covid-19 (accessed August 9, 2021)

111. Medicines and Healthcare products Regulatory Agency. Guidance on strain changes in authorised COVID-19 vaccines. 2021. https:// www.gov.uk/government/publications/access-consortium-guidance-on-strain-changes-in-authorised-covid-19-vaccines/guidance-on-strain-changes-in-authorised-covid-19-vaccines (accessed August 9, 2021)

112. European Medicines Agency. Reflection paper on the regulatory requirements for vaccines intended to provide protection against variant strain(s) of SARS-CoV-2. 2021. https://www.ema.europa. eu/en/documents/scientific-guideline/reflection-paper-regulatoryrequirements-vaccines-intended-provide-protection-against-variant_en.pdf (accessed August 9, 2021)

113. Therapeutic Goods Administration. TGA adopts Access Consortium guidance for fast-tracking authorisations of modified COVID19 vaccines for variants. 2021. https://www.tga.gov.au/tga-adoptsaccess-consortium-guidance-fast-tracking-authorisations-modified-covid-19-vaccines-variants (accessed August 9, 2021)

114. McGill COVID19 Vaccine Tracker Team. COVID-19 vaccine tracker. 2021. https://covid19.trackvaccines.org/vaccines/ (accessed August 9, 2021)

115. AstraZeneca. AZD1222 US phase III primary analysis confirms safety and efficacy. 2021. https://www.astrazeneca.com/mediacentre/press-releases/2021/azd1222-us-phase-iii-primary-analysisconfirms-safety-and-efficacy.html (accessed August 9, 2021)

116. ClinicalTrial.gov. Phase III trial of a COVID-19 vaccine of adenovirus vector in adults 18 years old and above. 2021. https:// clinicaltrials.gov/ct2/show/NCT04526990?term = vaccine \&cond $=$ covid-19\&draw $=6 \#$ wrapper $($ accessed August 9, 2021)

117. Jongeneelen M, Kaszas K, Veldman D, Huizingh J, van der Vlugt R, Schouten T, Zuijdgeest D, Uil T, van Roey G, Guimera N, Navis M, Bos R, le Gars M, Sadoff J, Muchene L, Juraszek J, Langedijk JPM, Vogels R, Custers J, Schuitemaker H, Brandenburg B. Ad26. COV2.S elicited neutralizing activity against Delta and other SARS-CoV-2 variants of concern. bioRxiv 2021: 2021.2007.2001. 450707

118. Novavax. Novavax confirms high levels of efficacy against original and variant COVID-19 strains in United Kingdom and South Africa Trials. 2021. https://ir.novavax.com/news-releases/newsrelease-details/novavax-confirms-high-levels-efficacy-against-original-and-0 (accessed August 9, 2021) 